\title{
The Relationship between Teachers' Educational Beliefs and Teaching-Learning Conceptions: A Mixed Method Study *
}

\author{
Eylem Yalçın İncik ${ }^{* *}$
}

\begin{abstract}
The aim of this study is; determining the relationship between teachers' education beliefs and their teaching-learning conceptions. A mixed method has been used to reach the overall aim of the research. In the study, the explanatory sequential design was used as mixed method design. In this context, quantitative data were collected and analysed at the first stage. In the second stage, qualitative data were collected to help explain the findings obtained after the analysis of the quantitative data. The study group of the quantitative dimension of the study constitutes 301 high school teachers who are working in secondary education institutions in the provincial centers of Mersin province during the 2015-2016 educational year and voluntarily participating in the research. The qualitative study group consists of 45 teachers from the quantitative dimension. Education Beliefs Scale, Teaching-Learning Conceptions Questionnaire and Interview Form were used in collecting research data. In the study, the analysis of the data was carried out in two stages: analysis of quantitative data and analysis of qualitative data. Anova was used to examine whether the educational beliefs of teachers and their teaching-learning conceptions differed according to the service year variable and t-test was used to see if it varied according to the gender variable. The relationship between teachers' educational beliefs and teaching-learning conceptions was examined by Pearson's correlation coefficient. Multiple linear regression analysis has been used to determine how teachers perceive their teaching-learning conception of educational beliefs. Content analysis was used for the analysis of qualitative data. It has been determined in the research that there is a significant relationship between teachers' educational beliefs and teaching-learning conceptions. In the study, it was determined that teachers' educational beliefs were a significant predictor of constructivist and traditional teaching-learning conceptions.
\end{abstract}

Keywords: educational belief, teaching-learning conceptions, teacher, mixed method

\footnotetext{
* A part of this research was presented as an oral presentation at the $4{ }^{\text {th }}$ International Congress on Curriculum and Instruction.

${ }^{* * *}$ Doctor in the field of Curriculum and Instruction, E-mail: ey alcinincik@ gmail.com
} 


\title{
Öğretmenlerin Eğitim İnançları ile Öğretme-Öğrenme Anlayışları arasındaki İlişsi: Bir Karma Yöntem Çalışması
}

\begin{abstract}
$\ddot{O} \mathbf{z}$
$\mathrm{Bu}$ araştırmanın amac1; öğretmenlerin eğitim inançlanı ile öğretme-öğrenme anlayış ları arasındaki ilişkinin belirlenmesidir. Araştırmanın genel amacına ulaşabilmek için karma yöntem kullanılmıştır. Araştırmada karma yöntem deseni olarak açımlayıcı sıralı desen kullanılmıştır. $\mathrm{Bu}$ kapsamda birinci aşamada nicel veriler toplanmış ve analiz edilmiştir. İkinci aşamada ise nicel verilerin analizi sonrasında elde edilen bulguların açıklanmasına yardımcı olacak nitel veriler toplanmıştır. Araştırmanın nicel boyutunun çalşma grubunu 2015-2016 eğitim öğretim yılında Mersin ili merkez ilçelerindeki orta öğretim kurumlarında görev yapmakta olan ve araştırmaya gönüllü katılım sağlayan 301 lise öğretmeni oluşturmaktadır. Nitel boyutun çalışma grubu ise nicel boyutta yer alan 45 öğretmenden oluşmaktadır. Araştırma verilerinin toplanmasında Eğitim İnançları Ölçeği, Öğretme-Öğrenme Anlayışları Ölçeği ve Görüşme Formu kullanılmıştır. Araştırmada verilerin analizi nicel verilerin analizi ve nitel verilerin analizi olmak üzere iki aşamada gerçekleştirilmiştir. Öğretmenlerin eğitim inançlarının ve öğretme-öğrenme anlayışlarının cinsiyet değişkenine göre farklılaşıp farklılaşmadığı T-Testi, hizmet yılı değişkenine göre farklılaşıp farklılaşmadığı ise ANOVA ile incelenmiştir. Öğretmenlerin eğitim inançları ile öğretme-öğrenme anlayışları arasındaki ilişki Pearson korelasyon katsayısı ile incelenmiştir. Öğretmenlerin eğitim inançlarının öğretme-öğrenme anlayışlarını ne oranda yordadığını belirlemek için ise çoklu doğrusal regresyon analizinden faydalanılmıştır. Nitel verilerin analizinde içerik analizi kullanılmıştır. Araştırmada öğretmenlerin eğitim inançları ile öğretme-öğrenme yaklaşımları arasında anlamlı ilişkiler olduğu belirlenmiş̧tir. Araştırmada, öğretmenlerin eğitim inançların in yapılandırmacı ve geleneksel öğretmeögrenme anlayışlarının anlamlı yordayıcısı olduğu belirlenmiştir.
\end{abstract}

Anahtar Sözcükler: eğitim inanc1, öğretme-öğrenme süreci, öğretmen, karma desen 


\section{Introduction}

One of the most important actors of the teaching-learning process in education is the teacher, and the other is the student. The role exhibited by the teacher; greatly affects the communication with the student, the role of the student in the teaching-learning process and therefore the performance they exhibit. Teacher behavior is also one of the factors determining the quality and efficiency of the teaching-learning process. For this reason, it is very important to determine the beliefs and conceptions behind the behaviors of the teachers in the teaching-learning process.

Belief as a system is an idea of the individual's reality, which contains enough truth to direct the individual's own views and behaviors (Harvey, 1986). Beliefs relate to subjects, events, and cognitive schemes that the individual considers as the truth (Krows, 1999). Sigel (1985), states that beliefs can be described as the "mental structures of experience". Hofer (2002), states that while beliefs are unconscious and implicit, it is possible that people are affected by these beliefs. Belief is also one of the factors that take part in the formation of the attitudes of the individual. Because the cognitive elements of attitude seen as preparatory tendencies to behavior consist of beliefs. For this reason, it can be said that the beliefs of the individuals are guiding their behaviour (Bandura 1977; Hofer \& Pintrich, 1997; Harvey, 1986; Hoy \& Miskel 2001; Krows, 1999; Pajares, 1992; Riggs \& Enochs, 1990).

Teaching is an extremely complex task, woven with both explicit and implicit personal values and beliefs. Since teaching is a process that requires evaluation, interpretation, and choice; it is not objective and unbiased by beliefs (Ramanowski, 1997). Pajares (1992), suggests a point of view that focuses on the assumptions based on the oldest philosophical thoughts of humanity in order to better understand teacher behaviours. Under every teacher's practices, there is a set of beliefs and values that are woven into their personal and professional fabric. These beliefs and values guide teachers' education programs and teaching decisions. Because this set includes teachers' individual life philosophies, habits and experiences. They all allow a teacher to understand their practices, their students, their subjects, their roles and responsibilities (Ramanowski, 1997).

It can be stated that the primary determinant of the educational beliefs of individuals is education philosophy (Yılmaz, Altıkkurt \& Çokluk, 2011). Education philosophy is a field of philosophy interested in the nature of human knowledge and its reasons (Hofer \& Pintrich, 1997). In the philosophy of education; problems related to the possibilities, nature, aims and methods of education are searched in response to various questions and are discussed with philosophical methods (Cevizci, 2000, p.305). Educational philosophy plays an important role in making decisions about educational programs. Because it is trying to determine the reasons for education and the reasons for the existence of schools, the ways, the types of environments in which individuals will be shaped, and the approaches (Doganay \& Sar1, 2003). To put it more clearly, education philosophy influences; selecting and interpreting goals, organising, presenting and teaching content, and making decisions about how to evaluate the success of the program (Ornstein \& Hunkins, 2009). In this context, philosophical movements seeking answers to the questions about the broad meaning of education have also directed the education practices in the direction of their predicted educational conceptions (Doğanay, 2011). In this study, the philosophical movements that represent the educational beliefs of teachers are discussed as Perennialism, Essentialism, Progressivism, Re-constructionism, and Existentialism. Educational conceptions predicted by these movements are briefly described below:

According to perennialism, seen as the most inflexible, conservative and traditionalist movement among educational trends, the reality is the basic, core and universal character of the man. All truth is in the mind. Individuals should be trained in the direction of constant facts like human nature and moral principles. For this reason, education should be shaped according to the universally unchangeable facts, principles and values, and the cultural values to be transferred should direct the person to the universal reality. For this reason, the teacher should gain the knowledge of universal truths and give importance to the intellectual education of the students. In perennialism, a teacher must be an expert in their field and be able to guide the discussion. According to perennialism, since the student is not at a level 


\section{THE RELATIONSHIP BETWEEN TEACHERS' EDUCATIONAL BELIEFS AND TEACHING-LEARNING CONCEPTIONS: A MIXED METHOD STUDY}

where they can judge the best knowledge and values they should learn, the interests and desires of the student are not taken into consideration (Arslan, 2002; Demirel, 2007; Gutek, 2007; Ornstein \& Hunkins, 1993; Sönmez, 2012; Sözer, 2002; Varış, 1994; Wiles \& Bondi, 2002).

In essentialism, it is argued that the real world is learned using reason, experiment, observation and research. Human minds are born empty. All information is learned later. Education should be based on the basic elements of human culture, knowledge, skills and events. For this reason, the school's basic function is to transfer and maintain in this manner. In Essentialism, a teacher must be an expert in the subject, knowing universal truths completely and precisely. Student; who is responsible for learning, who has no knowledge and skill, is the person who will be taught the knowledge and skill. Everything the teacher says must be memorized, done, repeated and the rules of the school must be obeyed without rejection (Ergün, 2012; Gutek, 2007; Kazu, 2002; Sönmez, 2012; Varış, 1994).

Progressivism is the form of education of the pragmatist philosophy. The main bearing of progressivism is change. For this reason, education should help people to understand changes and diversity as life itself. Individual differences are extremely important in progressivism. For this reason, the interests and abilities of the student must be considered. Education should be active, student-centered, and conducted in a way that is based on experiences and problem solving. In progressivism, the task of the teacher is to lead and guide (Bakır, 2014; Demirel, 2007; Sönmez, 2012; Sözer, 2002; Varış, 1994).

The goal of education in re-constructionism is to constantly rearrange and establish society. The basic responsibility for social change is laid on schools and teachers. Bringing out the talents and potential of the students, harbouring values such as development, love and cooperation, using the scientific method and developing critical thinking are among the objectives of re-constructionism. According to re-constructionism, learning takes place through problem-solving methods and trial-and-error and a democratic classroom environment where cultural differences are seen as richness (Bakır, 2014; Demirel, 2007; Ergün, 2012; Kaygisız, 1997; Sönmez, 2012; Varış, 1994).

According to existentialism, one can decide which way to choose, and this freedom of choice distinguishes it from all other beings in the world. The aim of education is to increase freedom. Knowledge is not objective and certain. Real knowledge is not obtained with reason; reality needs to be sensed more. Therefore, it includes feelings. For this reason, the value of the information is determined according to personally determined criteria. Since the nature of knowledge in existentialism includes them, the student should be able to choose the lesson and the teacher they want and leave it at any time. Students should be regarded as a whole. The teacher in existentialism; is a person who aids the student in need of assistance and is obliged to help develop their personality. The teacher can not guide students, but only when the student asks questions, they provide options about what they know; it is up to the student to use these options or not (Bilhan, 1991; Büyükdüvenci, 1994; Demirel, 2007; Sönmez, 2012; Varış, 1994).

Although the teachers' perspectives on education are not consciously framed by an educational philosophy, every teacher has a philosophy of education and teaching (Duman \& Ulubey, 2008). The beliefs of teachers regarding the nature of knowledge and learning; has a significant influence on the choices and decisions in the teaching-learning process (Chan \& Elliot, 2000; Chan \& Elliott, 2004; Eisner, 1992; Pajares, 1992). When the literature is examined, it is seen that there are strong links between teacher beliefs and teaching practices (Brown \& Rose, 1995; Cheng, Chan, Tang \& Cheng, 2009; Ennis, Cothran \& Loftus, 1997; Hashweh, 1996; Kagan, 1992; Leavy, McSorley \& Boté, 2007; Lefebvre, Deaudelin \& Loiselle, 2006; Nespor, 1987; Rienties, Lygo-Baker \& Brouwer, 2013; Savasc1-Ac1kalin, 2009; Yero, 2002).

Concepts regarding teaching and learning are often related to traditional and constructive learning models (Chan \& Elliot, 2004). According to Schunk (2014), there are 2 different teaching-learning conceptions in education (traditional-constructive) and these conceptions are opposed to each other. 
In the traditional teaching-learning conception, "learning" and "being informed" are synonymous concepts (Güneş, 2014). In this conception where a teacher-centered approach is taken, students are seen as empty pages where the information is written by the teacher. The teacher behaves didactically and presents the information to the students. They determine what will be learned, how it will be learned and the tempo and rhythm of learning (Brooks \& Brooks, 1997). This teaching-learning conception has its philosophical basis in prennialist and essentialist education philosophies (Phillips, 2003, as cited in Baş, 2015).

Constructivism, is a philosophical explanation on the nature of information (Airasian \& Walsh, 1998 as cited in Smith, 2002). In constructivism, information and how an individual obtains information is explained. In constructivism, it is claims that knowledge is structured by the individual themselves (Applefield, Huber \& Moallem, 2000; Cannon, 1997; Eggen \& Kauchak, 2001; Schunk, 2014). Brooks and Brooks (1999) define constructivism as a simple proposition "building our own understanding of the world we live in". In the constructivist conception, it is emphasized that new knowledge is formed by associating new information with previous information (Kauchak \& Eggen, 2003; Sherman \& Kurshan, 2005). According to this teaching-learning conception, students learn by choosing and developing their knowledge with individual and social activities. Information is not acquired, it's constructed (Phillips, 2000). In constructive teaching-learning conception, the teacher accepts the central role of the student and prioritises bringing out their points of view. Events that will provide experiences to support students in creating personal meanings will be constructed in the class. The lessons are based on basic concepts and big claims and the students' assumptions are questioned (Brooks \& Brooks, 1999). It is nourished by the philosophies of constructivism, progressivism, re-constructionism and existentialism and draws a projection to teaching and learning (Baş, 2015).

The basic components of education, which has an important function in the construction of the individual and the society the individual lives in, are; the education program, teacher and students. In order for education to be able to play a successful role in the community's constryction, it must first be shaped by the presence of that community's philosophy. Therefore, it is very important for the philosophy a society has, to be reflected on the education programmes and included in the application. Teachers are practitioners of educational programs. Teachers' choice during the implementation process is vitally important in education programmes reaching their goals. These preferences also have an important effect in meeting the expectations of education institutions formed by the philosophy of society. The teaching-learning conceptions of teachers, even if they have not received training for a certain educational philosophy trend in the pre-service training period, are influenced by their beliefs about the nature of knowledge and learning. These conceptions lie behind the decisions of teachers about what to focus on in the teachinglearning process, which methods to use, how to make evaluations, how to manage the class; meaning the individual preferences regarding the implementation of the education program. Therefore, it is considered to be important and necessary to examine the relationship between teachers' education beliefs and teaching-learning conceptions. In this context the main aim of this study is; determining the relationship between teachers' education beliefs and their teaching-learn conceptions. In the framework of this general aim, answers to the following questions were sought:

1. Do the teachers' educational beliefs and their teaching-learning conceptions show a significant difference according to the variables of gender and years of service?

2. Is there a significant relationship between the teachers' educational beliefs and their teaching-learning conceptions?

3. Are the educational beliefs of teachers predicting their teaching-learning conceptions?

4. What are the views of the teachers on the purpose of education?

5. What are the opinions of the teachers on the roles and responsibilities of the teacher and the student in the teaching-learning process? 


\section{THE RELATIONSHIP BETWEEN TEACHERS' EDUCATIONAL BELIEFS AND TEACHING-LEARNING CONCEPTIONS: A MIXED METHOD STUDY}

\section{Method}

\section{Research Model}

A mixed method has been used to reach the overall aim of the research. The mixed method involves philosophical assumptions guiding the management of data collection and analysis processes with a mix of qualitative and quantitative approaches at many stages of the research process. The basic premise of the mixed method is to use qualitative and quantitative data together so that the problem of research is understood better than any other method used alone (Creswell \& Plano Clark, 2007). In the study, explanatory sequential design was used as mixed method design. In this context, quantitative data were collected and analysed at the first stage. In the second stage, qualitative data were collected to help explain the findings obtained after the analysis of the quantitative data. The quantitative dimension of the research was designed in the relational screening model. It is aimed in this model to determine the relationship between two or more variables that can not be causally connected, can not be changed or examined for reasons of nature or practicality (Erkuş, 2011). In the qualitative dimension, the interview form approach included in the interview method was used. In the interview form approach, it is aimed to take the same kind of information from different individuals by approaching similar topics (McMillan \& Schumacher, 2006). In the interview form approach, the researcher has the freedom to ask both pre-prepared questions and additional questions in order to obtain more detailed information on those questions (Patton, 1987; as cited in Yildırım \& Şimşek, 2016). At the same time, it is possible to obtain more systematic and comparable information from different individuals (Yıldırım \& Şimşek, 2016). For this reason, this approach has been preferred in the qualitative aspect of the research. The mixed method model used in the research is given in Figure 1.

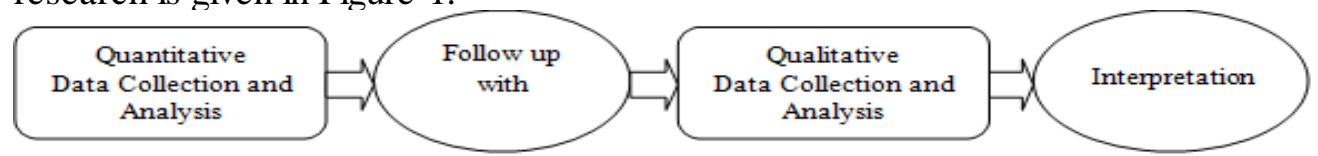

Figure 1. Diagram of the explanatory sequential design

The study group of the quantitative dimension of the study constitutes 301 high school teachers who are working in secondary education institutions in the provincial centers of Mersin province during the 2015-2016 educational year and voluntarily participating in the research. The qualitative study group consists of 45 teachers from the quantitative dimension. Out of the teachers who participated in the study, $48,2 \%(n=145)$ are women, and $51,8 \%(\mathrm{n}=156)$ are men. Of the teachers, $12,3 \%(\mathrm{n}=37)$ had $0-5$ years, $6 \%(\mathrm{n}=18)$ had $6-10$ years, $9,3 \%(n=28)$ had $11-15$ years, $27,6 \%(n=83)$ had $16-20$ years, $24,6 \%(n=74)$ had $21-$ 25 years and $20,3 \%(n=61)$ had 26 years and above seniority.

\section{Data Collection Tools}

Education Beliefs Scale, Teaching-Lerning Conceptions Questionnaire and Interview Form were used in collecting research data.

Education Beliefs Scale: In the scale developed by Yılmaz, Altınkurt and Çokluk (2011), there are 40 items. The scale is consisted of 5 sub scales; Progressivism, Existentialist Education, Re-constructionism, Perennialism and Essentialism. In the reliability analyses conducted by Y1maz, Altıkurt and Çokluk (2011), the cronbach alpha coefficients were calculated for each subscale; $.91, .89, .81, .70$ and .70 respectively. In the reliability analyses performed for this study, the Cronbach Alpha coefficients obtained for the subscales were; $.88, .82, .83, .70$ and .75 , respectively.

Teaching-Learning Conceptions Questionnaire: The questionnaire developed by Chan and Elliott (2004) and adapted to Turkish by Aypay (2011) includes 30 items. It is consisted of two sub-dimensions, constructivist and traditional teaching-learning conceptions. In the reliability analyses conducted by Aypay (2011), the cronbach alpha coefficient for the questionnaire was .71 and for the sub-dimensions was found to be .88 and .83 , respectively. In the reliability analyses performed for this study, the cronbach alpha 
coefficient for the questionnaire was .85; and .83 and .90 for the sub-dimensions, respectively.

Interview Form: In order to determine the teachers' beliefs towards education and their teaching-learning conceptions, a "Teacher Interview Form" developed by the researcher was used. In the first part of the two-part form, questions about the teachers' personal information and in the second part, questions about determining their educational beliefs and teachinglearning conceptions were asked. In the personal information section of the form there are three questions to determine the gender, seniority and branches of the teachers. In the second part, two open ended questions are given. In the open-ended questions, the teachers were asked what the main purpose(s) of education were and what the roles and responsibilities of teachers/students were in the teaching-learning process. Teachers were asked to respond by taking into account their own beliefs and definitions of teaching and their own classroom practices (and not what they thought should be). Prior to the application of the form, assistment was received from 3 teaching staff who were experts in Education Programs and Teaching and 3 teachers who were working in a high school affiliated to the Ministry of National Education in order to ensure coverage validity.

\section{Data Collection Process}

The data of the study were collected from the teachers working in different branches of high schools affiliated with Mersin provincial national education directorate. In the data collection process, first the purpose of conducting this research was explained to the teachers and then information was given about how to fill in data collection tools. Research was based on the teachers' voluntary participation. It took about two months to obtain the quantitative data of the study, and about one month for the qualitative data.

\section{Data Analys is}

In the study, the analysis of the data was carried out in two stages: analysis of quantitative data and analysis of qualitative data.

Prior to analysis of quantitative data, the assumptions of parametric tests were checked. It was determined that the obtained values indicate normal distribution. Therefore, it was decided to use parametric tests in the analysis of data. One-way Anova was used to examine whether the educational beliefs of teachers and their teaching-learning conceptions differed according to the service year variable and t-test was used to see if it varied according to the gender variable. The groups in which the significant differences arise because of the Anova analysis are determined by the Scheffe Test from Post-Hoc tests. The relationship between teachers' educational beliefs and teaching-learning conceptions was examined by Pearson's correlation coefficient. Multiple linear regression analysis has been used to determine how teachers perceive their teaching-learning conception of educational beliefs. Prior to regression analysis, autocorrelation and multiple links were examined between variables. Durbin Watson $(\mathrm{D}-\mathrm{W}=2.09)$ value showed that there was no autocorrelation among the significant variables. The multicollinearity assumptions of the data set were checked by the correlation between the predictor variables, the Variance Increase Factor (VIF) and the Tolerance Values (Tolerance $=1 / \mathrm{VIF}$ ), which is the variance value that the other independent variables can not account for. The relationship between the predictor variables is less than $0.80-0.90$, the VIF is less than 10 , and the Tolerance Value is greater than 0.2 , which means that there is no multiple link between the independent variables (Field, 2009, pp. 224-242). In this study, the highest correlation found between the predictive variables were $(\mathrm{r}=0.7)$, variance increase factor $(\mathrm{VIF}=1.38-2.55)$ and Tolerance Values $(0.393-0.722)$. The obtained values show that there is no multiple link between predictor variables and that the data set is suitable for multiple linear regression analysis.

Content analysis was used for the analysis of qualitative data. The main objective in content analysis is to reach concepts and relationships that can explain the collected data (Y1ldırım \& Şimşek, 2016, p.242). Content analysis is often used alongside other methods. The processes that will be used differs based on the objective of the analysis and the material that will be analysed (Büyüköztürk, Kılıç Çakmak, Akgün, Karadeniz \& Demirel, 2015, p.247). The main reason for using content analysis in this research is to obtain descriptive 


\section{THE RELATIONSHIP BETWEEN TEACHERS' EDUCATIONAL BELIEFS AND TEACHING-LEARNING CONCEPTIONS: A MIXED METHOD STUDY}

data to explain the research outcomes obtained with quantitative data. The basic process of content analysis is to bring together similar data within specific contexts and themes and interpret it in a way that the reader can understand. In this direction, the data obtained from the interview forms are primarily conceptualized and coded in the research. The obtained codes were arranged, and the codes thought to be related to each other were put together to create themes. When coding was performed, interview forms were named by sequence number and participant teachers are coded as $\mathrm{T} 1, \mathrm{~T} 2, \ldots$. Responses given by the participating teachers to the interview form were obtained by a researcher and a second researcher who is an expert in Education Programs and Teaching. The qualitative data set has been independently read and encoded by the researcher and expert. Codes and coding themes were examined together, and consistency was compared. The reliability of the study was calculated using the formula of Miles and Huberman (1994, p.64). The codes which are similar according to this form are called "agreement" and the codes which are different are called "disagreement". The agreement percentage for encoder reliability is calculated with the formula Reliability=Number of agreements/ (Number of agreements+Number of disagreements)*100. In this study, the reliability between coders was calculated as .82 for the first question and .82 for the second question. $70 \%$ or higher fit percentage indicates that the reliability between the encoders is sufficient. The frequencies of the theme-related codes obtained as a result of the content analysis are presented in tabular form and are directly supported by quotes from the participants' opinions.

\section{Results}

In this part of the study, the findings obtained due to the aim of the research and the research questions are included. For this reason, in the context of research questions, the findings from the qualitative data set were presented first, followed by the findings from the quantitative data set.

\section{Findings Related to the Quantitative Data Set}

The first question of the study was stated as "Do the teachers' educational beliefs and their teaching-learning conceptions show a significant difference according to the variables of gender and years of service?". The results of t-test and Anova that teachers' educational beliefs and teaching-learning conceptions differed significantly according to gender and years of service were analysed and the findings are given in Table 1 and Table 2

Table 1. T-Test results according to gender variable of teachers' educational beliefs and teaching learning conceptions

\begin{tabular}{|c|c|c|c|c|c|c|c|c|}
\hline Educational Belief & Gender & $\mathbf{N}$ & $\mathbf{x}$ & $\mathbf{S}$ & df & $\mathbf{t}$ & $\mathbf{p}$ & Effect Size \\
\hline \multirow{2}{*}{ Progressivism } & Female & 145 & 58.56 & 5.12 & \multirow{2}{*}{299} & \multirow{2}{*}{1.88} & \multirow{2}{*}{0.61} & \\
\hline & Male & 156 & 57.39 & 5.59 & & & & \\
\hline \multirow{2}{*}{ Existentialism } & Female & 145 & 32.71 & 2.87 & \multirow{2}{*}{299} & \multirow{2}{*}{1.68} & \multirow{2}{*}{0.93} & \\
\hline & Male & 156 & 32.08 & 3.51 & & & & \\
\hline \multirow{2}{*}{ Re-Constructionism } & Female & 145 & 29.74 & 4.50 & \multirow{2}{*}{299} & \multirow{2}{*}{1.04} & \multirow{2}{*}{0.29} & \multirow{6}{*}{0.02} \\
\hline & Male & 156 & 29.18 & 4.74 & & & & \\
\hline \multirow{2}{*}{ Essentialism } & Female & 145 & 12.36 & 4.52 & \multirow{2}{*}{299} & \multirow{2}{*}{2.10} & \multirow{2}{*}{$0.03^{*}$} & \\
\hline & Male & 156 & 13.42 & 4.23 & & & & \\
\hline \multirow{2}{*}{ Perennialism } & Female & 145 & 32.90 & 4.92 & \multirow{2}{*}{299} & \multirow{2}{*}{0.64} & \multirow{2}{*}{0.52} & \\
\hline & Male & 156 & 33.25 & 4.80 & & & & \\
\hline $\begin{array}{l}\text { Teaching-Learning } \\
\text { Conception }\end{array}$ & Gender & $\mathbf{N}$ & $\mathbf{x}$ & $\mathbf{S}$ & df & $\mathbf{t}$ & $\mathbf{p}$ & Effect Size \\
\hline \multirow{2}{*}{ Constructivist } & Female & 145 & 53.41 & 5.02 & \multirow{2}{*}{299} & \multirow{2}{*}{2.48} & \multirow{2}{*}{$0.01 *$} & \multirow{4}{*}{0.02} \\
\hline & Male & 156 & 51.85 & 5.79 & & & & \\
\hline \multirow[t]{2}{*}{ Traditional } & Female & 145 & 48.29 & 14.11 & \multirow{2}{*}{299} & \multirow{2}{*}{1.58} & \multirow{2}{*}{0.11} & \\
\hline & Male & 156 & 50.76 & 13.00 & & & & \\
\hline
\end{tabular}

The results of the t-test for the gender variable showed that there was no significant difference in the educational beliefs of the teachers according to the sub-dimensions of progressivism, existentialism, re-constructionism and perennialism. In contrast, in the subdimension of essentialism, it is concluded that there is a significant difference in favor of 
male teachers. In the teachers' teaching-learning conceptions, it is concluded that there is a significant difference in favor of female teachers in the constructivist sub-dimension.

Table 2. Anova results according to years of service variable of teachers' educational beliefs and teaching-learning conceptions

\begin{tabular}{|c|c|c|c|c|c|c|c|}
\hline Educational Belief & $\begin{array}{l}\text { Sum of } \\
\text { Squares }\end{array}$ & df & $\begin{array}{l}\text { Mean } \\
\text { Square } \\
\end{array}$ & $\mathbf{F}$ & $\mathbf{p}$ & Difference & $\begin{array}{c}\text { Effect } \\
\text { Size } \\
\end{array}$ \\
\hline Progressivism & $\begin{array}{c}290.250 \\
8442.014 \\
8732.264\end{array}$ & $\begin{array}{c}5 \\
295 \\
300\end{array}$ & $\begin{array}{l}58.050 \\
28.617\end{array}$ & 2.019 & .75 & - & \\
\hline Existentialism & $\begin{array}{c}91.459 \\
3041.030 \\
3132.489\end{array}$ & $\begin{array}{c}5 \\
295 \\
300\end{array}$ & $\begin{array}{l}18.292 \\
10.309\end{array}$ & 1.774 & .118 & - & \\
\hline Re-Constructionism & $\begin{array}{c}201.048 \\
6248.294 \\
6449.342\end{array}$ & $\begin{array}{c}5 \\
295 \\
300\end{array}$ & $\begin{array}{l}40.210 \\
21.181\end{array}$ & 1.898 & .094 & - & \\
\hline Essentialism & $\begin{array}{c}332.187 \\
5481.206 \\
5813.392\end{array}$ & $\begin{array}{c}5 \\
295 \\
300\end{array}$ & $\begin{array}{l}66.437 \\
18.580\end{array}$ & 3.576 & $.004 *$ & $\begin{array}{c}21-25>0-5 \\
26 \text { years and } \\
\text { over }>0-5\end{array}$ & $\begin{array}{l}0.197 \\
0.189\end{array}$ \\
\hline Perennialism & $\begin{array}{c}184.802 \\
6901.927 \\
7086.730 \\
\end{array}$ & $\begin{array}{c}5 \\
295 \\
300 \\
\end{array}$ & $\begin{array}{l}36.960 \\
23.396\end{array}$ & 1.580 & .166 & 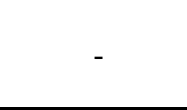 & \\
\hline $\begin{array}{l}\text { Teaching-Learning } \\
\text { Conception }\end{array}$ & $\begin{array}{l}\text { Sum of } \\
\text { Squares }\end{array}$ & df & $\begin{array}{l}\text { Mean } \\
\text { Square } \\
\end{array}$ & $\mathbf{F}$ & $\mathbf{p}$ & Difference & $\begin{array}{l}\text { Effect } \\
\text { Size }\end{array}$ \\
\hline Constructivist & $\begin{array}{c}340.182 \\
8690.791 \\
9030.973\end{array}$ & $\begin{array}{c}5 \\
295 \\
300\end{array}$ & $\begin{array}{l}68.036 \\
29.460\end{array}$ & 2.309 & $.044 *$ & $\begin{array}{c}0-5>21-25 \\
0-5>26 \text { years } \\
\text { and over }\end{array}$ & $\begin{array}{l}0.155 \\
0.156\end{array}$ \\
\hline Traditional & $\begin{array}{l}2205.730 \\
52937.06 \\
55142.79\end{array}$ & $\begin{array}{c}5 \\
295 \\
300\end{array}$ & $\begin{array}{l}441.146 \\
179.448\end{array}$ & 2.458 & $.033^{*}$ & $\begin{array}{c}21-25>0-5 \\
26 \text { y ears and } \\
\text { over }>0-5\end{array}$ & $\begin{array}{l}0.148 \\
0.125\end{array}$ \\
\hline
\end{tabular}

As a result of the Anova, which was conducted to determine whether the educational beliefs of the teachers differed in terms of the years of service variable, there is no significant difference in progressivism, existentialism, re-constructionism and perennialism subdimensions. According to the sub-dimension of essentialism, a significant difference is reached. As a result of the Scheffe-test performed to determine between which groups are the differences in this sub-dimension, it was seen that the difference was between teachers with 0-5 years of service and teachers between 21-25 years and 26 years and over service.

As a result of the Anova analysis to determine whether the teacher's teaching-learning conceptions differed with the service-year variable perspective, it was concluded that there was a significant difference according to the constructivist and traditional sub-dimensions. As a result of the Scheffe-test performed to determine which groups differ in these subdimensions, both sub-dimensions were found to be teachers with 0-5 years of service and teachers between 21-25 years and 26 years and over service.

The second question of the study was stated as "Is there a significant relationship between the teachers' educational beliefs and their teaching-learning conceptions?". A Pearson correlation analysis was conducted to investigate the relationship between teachers' beliefs of education and their teaching-learning conceptions. The findings are presented in Table 3.

Table 3. Pearson correlation analysis results of teachers' relations between educational beliefs and teaching-learning conceptions

\begin{tabular}{|c|c|c|c|c|}
\hline \multirow[t]{2}{*}{ Educational Belief } & \multicolumn{2}{|c|}{ Constuructivist } & \multicolumn{2}{|c|}{ Traditional } \\
\hline & $\mathbf{r}$ & $\mathbf{p}$ & $\mathbf{r}$ & p \\
\hline Progressivism & .618 & .000 & -.210 & .000 \\
\hline Existentialism & .638 & .000 & -.233 & .000 \\
\hline Re-constructionism & .443 & .000 & .072 & .215 \\
\hline Essentialism & -.175 & .002 & .660 & .000 \\
\hline Perennialism & -.273 & .000 & .296 & .000 \\
\hline
\end{tabular}




\section{THE RELATIONSHIP BETWEEN TEACHERS' EDUCATIONAL BELIEFS AND TEACHING-LEARNING CONCEPTIONS: A MIXED METHOD STUDY}

As a result of analysis, constructist teaching-learning conception of teachers and have a significant positive correlation between beliefs of progressivism $(\mathrm{r}=.618, \mathrm{p}<0.01)$, existentialism $(\mathrm{r}=.638, \mathrm{p}<0.01)$ and re-constructionism $(\mathrm{r}=.443, \mathrm{p}<0.01)$; and there is a significant negative relationship between the beliefs of essentialism $(\mathrm{r}=-.175, \mathrm{p}<0.01)$ and perennialism $(\mathrm{r}=-.273, \mathrm{p}<0.01)$. There is a positive relationship between teachers' traditional teaching-learning conceptions and essentialism $(\mathrm{r}=.660, \mathrm{p}<0.01)$ and perennialism $(\mathrm{r}=.296$, $\mathrm{p}<0.01)$ educational beliefs; existentialism $(\mathrm{r}=.-233, \mathrm{p}<0.01)$ and progressivism $(\mathrm{r}=-.210$, $\mathrm{p}<0.01)$ educational beliefs were found to be negatively and significantly related to educational beliefs. However, it has been found that there is no significant relationship between the teachers' traditional teaching-learning conceptions and the re-constructionism $(\mathrm{r}=.072, \mathrm{p}>0.01)$ educational belief.

The third question of the study was stated as "Are the educational beliefs of teachers predicting their teaching-learning conceptions?". Multiple regression findings for predicting teachers' constructivist and traditional teaching-learning conception of educational beliefs are given in Table 4 and Table 5.

Table 4. Results of multiple regressions on the predictions of constructivist teaching-learning conceptions of teachers'educational beliefs

\begin{tabular}{|c|c|c|c|}
\hline \multirow[b]{2}{*}{ Predictive Variables } & \multicolumn{3}{|c|}{ Constructivist Teaching-Learning Conception } \\
\hline & $\beta$ & $t$ & $p^{*}$ \\
\hline (Constant) & - & 3.949 & .000 \\
\hline Progressivism & .296 & 4.323 & .000 \\
\hline Existentialism & .385 & 5.710 & .000 \\
\hline Re-constructionism & .089 & 1.496 & .136 \\
\hline Essentialism & .007 & 0.147 & .883 \\
\hline \multirow[t]{2}{*}{ Perennialism } & .035 & 0.616 & .538 \\
\hline & $\mathrm{R}=0.676$ & 49.729 & \\
\hline
\end{tabular}

As a result of the multiple linear regression analysis conducted to determine the extent to which teachers' beliefs explain the change in their constructivist teaching-learning conception, it is seen that the variables of progressivism, existentialism, re-constructionism, essentialism and perennialism educational beliefs have a significant relationship $(\mathrm{R}=0.676$, $\left.\mathrm{R}^{2}=0.46\right) \quad$ with constructivist teaching-learning conception $(\mathrm{F}(5-295)=49.729, \mathrm{p}<0.01)$. In particular, five educational beliefs together account for $46 \%$ of the change in teachinglearning conceptions. According to the standardized regression coefficients $(\beta)$, the order of importance of the predictive variables on the constructivist teaching-learning conception are; existentialism $(\beta=0.385)$, progressivism $(\beta=0.296)$, re-constructionism $(\beta=0.089)$, perennialism $(\beta=0.035)$ and essentialism $(\beta=0.007)$. When the significance tests of the regression coefficients are taken into consideration, it is seen that only progressivism $(\mathrm{p}<0.01)$ and existentialism $(\mathrm{p}<0.01)$ from the predictive variables are predictive of the constructivist teaching-learning conception.

Table 5. Results of multiple regressions on the predictions of traditional teaching-learning conceptions of teachers'educational beliefs

\begin{tabular}{|c|c|c|c|}
\hline \multirow[b]{2}{*}{ Predictive Variables } & \multicolumn{3}{|c|}{ Traditional Teaching-Learning Conception } \\
\hline & $\boldsymbol{\beta}$ & $\mathbf{t}$ & $\mathbf{p}^{*}$ \\
\hline (Constant) & - & 4.613 & .000 \\
\hline Progressivism & .065 & 0.953 & .341 \\
\hline Existentialism & 137 & 2.049 & .041 \\
\hline Re-constructionism & .060 & 1.020 & .309 \\
\hline Essentialism & .555 & 11.079 & .000 \\
\hline Perennialism & .171 & 3.020 & .003 \\
\hline
\end{tabular}

As a result of the multiple linear regression analysis conducted to determine the extent to which teachers' beliefs explain the change in traditional teaching-learning conception, it is seen that the variables of progressivism, existentialism, re-constructionism, essentialism and perennialism educational beliefs together show a significant relationship $\left(R=0.683, R^{2}=0.47\right)$ 
with traditional teaching-learning conception. That is, five educational beliefs together explain $47 \%$ of the change in teaching-learning conception. According to the standardised regression coefficients $(\beta)$, the relative importance of the predictive variables over the traditional teaching-learning conception are; essentialism $(\beta=0.555)$, perennialism $(\beta=0.171)$, existentialism $(\beta=0.137)$, progressivism $(\beta=0.065)$ and re-constructionism $(\beta=0.060)$, respectively. When the significance tests of the regression coefficients are taken into consideration, it is seen that out of the predictive variables only essentialism $(p<0.01)$ and perennialism $(\mathrm{p}<0.01)$ are significant predictive variables of the traditional teaching-learning conception.

\section{Findings Related to the Quantitative Data Set}

Two open-ended questions were included in the study in order to determine the views of the teachers about the roles and responsibilities of the teacher and the student in the teachinglearning process and the objectives of education. The first open-ended question in the interview form is expressed as "What is the main purpose of education as a system for you?". The responses of the participants to the open-ended question are presented in Table 6 and were also directly supported by quotes from the participants' opinions.

Table 6. Teachers' views on educational purposes as a system

\begin{tabular}{|c|c|c|c|c|c|c|}
\hline \multirow{5}{*}{ 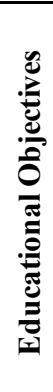 } & Social & f & Educational & f & $\begin{array}{c}\text { Towards the } \\
\text { Individual's } \\
\text { Achievement }\end{array}$ & f \\
\hline & $\begin{array}{l}\text { Transfering national and } \\
\text { ethical values }\end{array}$ & 12 & $\begin{array}{l}\text { To give students } 21 \mathrm{st} \\
\text { century skills }\end{array}$ & 13 & Prepare for the future & 12 \\
\hline & Raising conscious citizens & 9 & To give behaviour & 5 & To gain self-confidence & 2 \\
\hline & $\begin{array}{l}\text { Conveying cultural values } \\
\text { as a social gain }\end{array}$ & 5 & Teaching to learn & 4 & & \\
\hline & $\begin{array}{l}\text { To raise generations related } \\
\text { to Atatürk's principles and } \\
\text { reforms }\end{array}$ & 2 & $\begin{array}{l}\text { Raising student } \\
\text { potential }\end{array}$ & 2 & & \\
\hline
\end{tabular}

When Table 6 is examined, it is seen that teacher opinions fall under three sub-themes. Teachers think education has three main objectives; "social", "educational" and "towards the individual's achievement". When the most commonly agreed upon points of the teachers are examined, the objectives of education as an educational system were, transfering national and ethical values (12), raising conscious citizens (9) and conveying cultural values as a social gain (5); educational objectives were to give students 21 st century skills (13) and behaviour (5); and the objective for individual achievement were to prepare for the future (12). Some of the views of teachers on the objectives of education as a system are as follows:

"The aim of education is to educate and raise citizens who give importance to the national values and work for the welfare of the nation." (T28)

"The purpose of education is to lay the foundations of a person to be raised into a citizen who is useful for their country, their family and themselves." (T26)

"In my opinion, the main aim of education as a system is to train citizens/individuals who are ready for the future by first adhering to moral principles and culture." (T14)

"The main aim of education is to train the students to prepare for the future with the qualities that they can apply throughout their lives." (T34)

The second open-ended question in the interview form is "What are the roles and responsibilities of the teacher and the student in the teaching-learning process?" The responses of the participants to the open-ended question are presented in Table 7 and were also directly supported by quotes from the participants' opinions. 


\section{THE RELATIONSHIP BETWEEN TEACHERS' EDUCATIONAL BELIEFS AND TEACHING-LEARNING CONCEPTIONS: A MIXED METHOD STUDY}

Table 7. Teachers' views on teacher/student roles and responsibilities in the teaching-learning process

\begin{tabular}{|c|c|c|c|c|}
\hline \multirow{13}{*}{ 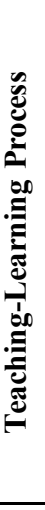 } & Teacher Roles and Responsibilities & f & Student Roles and Responsibilities & f \\
\hline & Being a guide & 18 & To be willing to learn & 14 \\
\hline & Being a role model & 12 & To have a sense of responsibility & 11 \\
\hline & Transference & 5 & To have a questioning and investigative identity & 7 \\
\hline & Self-improvement & 5 & To be active & 6 \\
\hline & Uncovering student talents & 2 & To follow the rules & 6 \\
\hline & Teaching to learn & 1 & To do homework, listen and repeate the lesson & 4 \\
\hline & Selfless work & 1 & To speak in place and on time & 3 \\
\hline & To be an actor & 1 & Being innovative & 1 \\
\hline & $\begin{array}{l}\text { Raising individuals who are respectful of } \\
\text { their values, nation and humanity }\end{array}$ & 1 & Being entrepreneur & 1 \\
\hline & & & Being result-oriented & 1 \\
\hline & & & Being a planned person & 1 \\
\hline & & & To express ideas freely & 1 \\
\hline
\end{tabular}

When Table 7 is examined, it is seen that the points that most teachers agree on as their roles and responsibilities in the teaching-learning process are being a guide (18), being a role model (12), transference (5) and self-improvement (5). Some of the teachers' views on their roles and responsibilities in the teaching-learning process are as follows:

"They should be the guides and leaders in the teaching-learning process. They must play a role in revealing the talents of the students." (T17)

"The teacher should be the guide to the source of information. To be able to do this, they must be responsible for developing themselves constantly." (TI)

"The teacher must be like a compass showing the way. They should not try to change the child's self. They should show that there are different ways and options in life." (T41)

"The teacher should be able to direct the students correctly. Apart from the transfer of knowledge, they must also provide intellectual development. They must be able to teach that every work done must be respected." (T40)

"In the present system, student-teacher roles are intertwined and occasionally overlap. The roles should be clear, and the roles of the teacher are teaching and transference." (T38)

When the most common points of teachers' views on student roles and responsibilities in the teaching-learning process are examined, these are seen as; to be willing to learn (14), to have a sense of responsibility (11), to have a questioning and investigative identity (7), to be active (7), to follow the rules (6) to do homework, to listen and repeate the lesson (4). Some of the teachers' views on student roles and responsibilities in the teaching-learning process are as follows:

"Students should not be passive listeners, they should be participants, active and inquisitive." (T30)

"The basic role and responsibility of students are being are of their responsibility and duties, and finishing the tasks set for them in a disciplined manner." (T39).

"First of all, they should come to school willingly so that we can teach them something."

"They should be respectful to themselves and people around them, revise their classes, do their homework and also not neglect themselves." (T43)

"Once the student has achieved proper behaviour, they should fulfill all responsibilities on time. The student is obliged to fulfill the homeworks given." (T26) 


\section{Discussion}

This research was conducted to determine the relationship between teachers' educational beliefs and their teaching-learning conceptions. In this context, educational beliefs and teaching-learning conceptions of teachers are examined according to variables of gender and years of service.

When the findings of the study were examined, it was found that there was no significant difference in the educational beliefs of the teachers regarding progressivism, existentialism, re-constructionism and perennialism educational beliefs, whereas there was a significant difference in favor of male teachers in the essentialism educational belief. When the literature is examined, it is seen that similar results are obtained in different studies which support this finding. Significant differences were found in favor of male teacher candidates in the belief in essentialism in the studies of Alkın Şahin, Tunca and Ulubey (2014), Akgün (2015) and Yazıc1 (2017). In the study conducted by Ylmaz and Tosun (2013), the opinions of the teachers about the educational philosophies differed according to the gender, and the findings showed that the male teachers agreed more than the female teachers in the philosophies of perennialism and essentialism. Similarly, in the study of Beytekin and Kadı (2015), it was found that gender of the teacher candidates is a variable that makes a difference in educational beliefs and that male teacher candidates have higher points than female teacher candidates in the belief of perennialism. There are also studies in the field that do not support this finding. Findings indicate that gender is not a significant variable in terms of educational beliefs/educational philosophical beliefs in the study groups conducted with different working groups (teacher, teacher candidate, education managers) (Altınkurt, Yılmaz \& Oğuz, 2012; Biçer, Er \& Özel, 2013; Çelik \& Orçan, 2016; Doğanay \& Sarı, 2003; Erbaş, 2013; Ilgaz, Bülbül \& Çuhadar, 2013; Karadağ, Baloğlu \& Kaya, 2009; Türkeli, 2011; Uğurlu \& Çalmaşur, 2017). Another noteworthy finding is that when the educational beliefs of teachers are examined in terms of the gender variable, it is not surprising that female teachers are favored in the beliefs of progressivism, existentialism and re-constructionism, which are regarded as beliefs in contemporary educational philosophy, and the average of the male teachers are higher in the beliefs of perennialism and essentialism. When the field literature is examined in the context of this finding, it is seen that there are studies that obtained similar results (Alkın Şahin, Tunca \& Ulubey, 2014; Biçer, Er \& Özel, 2013; Beytekin \& Kad,, 2015).

According to another finding of the research, gender variable makes a significant difference in favor of female teachers on constructivist teaching-learning conceptions of teachers. It does not make a significant difference in the traditional teaching-learning conceptions. However, the average grades of male teachers in traditional teaching-learning conception are higher than those of female teachers. When the field literature is examined, it is seen that different results were obtained. In the study of Aypay (2011), it was determined that the concept of teaching-learning differentiated according to the gender, the female teacher candidates had a higher score in the constructivist teaching-learning conception and the male teacher candidates had a higher score in the traditional teaching-learning conception. In the study of Baş (2014), it was determined that there was no significant difference in teachers' constructivist teaching-learning conceptions in terms of the gender variable, but that there was a significant difference in favor of male teachers in traditional teaching-learning conceptions. In the study conducted by Aydm, Tunca and Alkın-Şahin (2015), it was found that gender of the teacher candidates was a variable that made a difference in their preferences for constructivist teaching-learning conception and that they did not make a difference in their preference for traditional teaching-learning conception. However, in the aforementioned study, it was seen that male teacher candidates preferred the constructivist teaching-learning approach more than female teacher candidates, unlike this study. In the study carried out by Oğuz (2011), it was seen that the scores of the male teacher candidates in the traditional teaching-learning conceptions were significantly higher, but there was no significant difference when it came to constructivist teaching-learning conceptions. Aykan (2014), Ekinci (2016), Engin and Daşdemir (2015), differing from the finding of this study, found that the gender of teachers did not make a significant difference on their preferred teaching-learning understanding. 


\section{THE RELATIONSHIP BETWEEN TEACHERS' EDUCATIONAL BELIEFS AND TEACHING-LEARNING CONCEPTIONS: A MIXED METHOD STUDY}

According to another finding from the survey, years of service variable of teachers do not make a significant difference in the educational beliefs of progressivism, existentialism, re-constructionism and perennialism. However, there is a significant difference between teachers who have 0-5 years of service and teachers with 21-25 and 26 years or more. When the field literature is examined in terms of this finding, it is seen that different results were obtained. In the study performed by Aslan (2017), it was found that there is a significant difference in perennialism educational beliefs between classroom teachers whose years of service are $0-5$ years and the teachers who are 6-10,11-15 and 16 years or more. In the study performed by Kanatlı and Schreglman (2014) on primary school teachers, it became clear that there was a significant difference in favor of teachers in the first five years of their profession in perennialism education belief. Yllmaz and Tosun (2013) found that teachers' years of service did not make a difference in their progressivism, existentialism and reconstructionism educational beliefs, but they made a significant difference in favor of teachers who had more seniority, with perennialism and essentialism educational beliefs.

According to another finding of the study, the years of service variable makes a significant difference in the constructivist and traditional teaching-learning conceptions of the teachers. In the study, it was found that there was a significant difference between the teachers who were 0-5 years in service and the teachers who were 21-25 and 26 years or morein service, in both constructivist and traditional teaching-learning conceptions. This difference was found to favor teachers who had 0-5 years in service in the constructivist teaching-learning conception, whereas in the traditional teaching-learning conception, it was in favor of teachers with 21-25 and 26 years or more service. This finding can be interpreted as a recently graduated teacher who was trained in constructivism adopting a more studentcentered approach than colleagues whose years of service are longer and whose undergraduate studies have been completed quite a long time ago. This finding is consistent with the findings of the study conducted by Baş (2014). In the study of Baş (2014), it was determined that, as the occupational seniority increases, the more traditional teachinglearning concept is adopted, while the younger teachers with less occupational seniority adopt the constructivist teaching-learning approach. In the study conducted by Ekinci (2016), a significant difference was only found between the occupational seniority of teachers and traditional teaching-learning conception, and this difference was found to be in favor of class teachers with high occupational seniority.

In the study, there was a significant positive relationship between teachers' constructivist teaching-learning conceptions and progressivism, existentialism and reconstructionism educational beliefs; and there was a significant negative relationship between essentialism and perennialism educational beliefs. There is a positive significant relationship between teachers' traditional teaching-learning conception and essentialism and perennialism education beliefs; existentialism and progressivism educational beliefs were found to be negatively and significantly related. These findings show that teachers' beliefs about education and their teaching-learning conceptions are closely related. This finding of the survey is parallel to the findings of studies conducted by Aslan (2017) and Baş (2015). In these studies, it was determined that the relationships between the educational beliefs of the teacher candidates/teachers and the teaching-learning understandings were investigated and found to be significant.

In the study, it was determined that teachers' educational beliefs were a significant predictor of constructivist and traditional teaching-learning conceptions. It has been found that teachers' beliefs of education account for $46 \%$ of the constructivist teaching-learning conception and $47 \%$ of the traditional teaching-learning conception in the total variance. However, it has been determined that educational beliefs of existentialism and progressivism are significant predictors of constructivist teaching-learning conceptions and perennialism and essentialism education beliefs are significant predictors of traditional teaching-learning conceptions. These findings show that the teaching-learning conception of teachers with the belief of perennialism and essentialism towards education are aimed towards traditional teaching-learning conceptions, and the teaching-learning concept of teachers with progressivism and existentialism educational beliefs are shaped towards the constructivism teaching-learning conception. It can be said that the teachers who have the belief of 
contemporary educational philosophy will conduct activities that are constructivist, and teachers with traditional (perennialism and essentialism) educational philosophies will conduct activitiees that are more traditional in the teaching-learning process. In this context, it is expected that teachers with progressivist and existential educational beliefs will be able to improve their potential by considering the interests and abilities of the students, in order to enrich the students' perspective on the role of the student in all stages of the teachinglearning process by applying activities that focus on experience and learning by doing/living. In the same way, for teachers who have perennialism and essentialism educational beliefs; it can be said that in all stages of the teaching-learning process they will determine students as passive recipients and they themselves, as experts and authorities; and will apply activities to transfer the knowledge and cultural heritage of society in a way that is based on universal principles, absolute unchangeables, and where the students will be passive recipients of information.

When the findings obtained from the qualitative data of the research are examined, it is seen that the opinions of the teachers about the objectives of education take place under three sub-themes; social, educational and individual acquisition purposes. It is a remarkable point that teacher's state opinions more on social purposes rather than educational purposes. This finding suggests that teachers consider national and moral values as a primary purpose of education by educating their students and transferring the common cultural heritage to these citizens to continue social existence. In the educational objectives "acquisition of $21 \mathrm{st}$ century skills by students" can be assessed in the way that teachers see today as being one of the basic functions of education, that is to say, acquiring the skills that are accepted today and believed to be possessed by individuals of a society. Also, the expression of "attaining behavior", which is included in educational purposes, also suggests that teachers see education as a means of shaping the individual. This finding, when examined in the context of educational beliefs, can be said to be parallel to the education definitions of perennialist and essentialist educational philosophies. Considering the "Towards the Person's Achievement" objectives, it is seen that there are fewer opinions than the other sub-themes. In this sub-theme, teachers describe the purpose of education as the preparation of the individual for the future by enabling them to acquire the learning outcomes for sustaining their life. This finding can be said to be parallel to the educational definitions of the educational philosophies of existentialism and progressivism when examined in the context of educational beliefs.

Another finding of the research relates to the opinions of the teachers regarding the roles and responsibilities of the teacher/student in the teaching-learning process. It can be said that teachers mostly define the roles and responsibilities that a teacher should have in the teaching-learning process in accordance with the constructivist teaching-learning approach. However, it seems that these definitions are quite limited. However, expressions of "transfer" and "being an actor" can be assessed in such a way that some of the teachers have taken a role in directing information to students, that they have chosen a traditional teaching-learning conception where students are passive. When teachers' views on student roles and responsibilities in the teaching-learning process are examined, it can be said that they have define the roles and responsibilities mostly in the context of constructivist teaching-learning conception, similar to their definitions of their roles and responsibilities they see for teachers. Teachers think that students should be especially willing to learn and have a sense of responsibility. However, some teachers describe the roles and responsibilities of students in a behavior-focused, disciplined way, with one-sided communication based on certain predetermined rules, and making homework and revisions the primary responsibility; with phrases such as "acting in accordance with the rules", "doing homework", "listening / repeating the lesson" and "on-site and on-time speaking" in the context of a teachinglearning process. This definition, made by some teachers, also supports the definition of their roles and responsibilities in the context of traditional teaching-learning conception.

There are many questions in education whose answers are sought. "What is learning?", "What is effective teaching?", "What is effective teaching related to learning?", "What are the role and responsibilities of the teacher and the student in the learning and teaching process?" are just a few of them. Being able to answer all these questions is important for 


\section{THE RELATIONSHIP BETWEEN TEACHERS' EDUCATIONAL BELIEFS AND TEACHING-LEARNING CONCEPTIONS: A MIXED METHOD STUDY}

everyone involved in the teaching-learning process. Because these questions are a result of the search for solutions that can be used to answer the question "How should a good teaching be?" When teachers respond to the above questions within their contexts and classes, they also offer personal descriptions of effective teaching. In this context, every teacher is as unique as every student (Kauchak and Eggen, 2003). It is a fact that many variables can play a role in the differentiation and personal definitions of teachers' thoughts, preferences and practices regarding learning and teaching. It has been emphasised many times in the literature that education philosophy is believed to be one of the aforementioned variables. In this research, findings in support of the field literature were obtained and the following suggestions based on the results of the research are presented.

In this study, quantitative data and qualitative data were used together to try to obtain profound findings about the relationship between teachers' educational beliefs and their teaching-learning approaches. In similar studies to be done, more detailed data can be obtained by using different qualitative data collection methods, such as observation along with the interviews, in order to obtain application-based data. At the same time, research can be conducted on different variables that are thought to be related to educational beliefs and teaching-learning conceptions.

It has been determined in the research that there is a significant relationship between teachers' educational beliefs and teaching-learning conceptions. In this context, it can be said that the classes teachers' take regarding their educational beliefs in pre-service education may be effective in the applications that they show in their professional lives. For this reason, it can be suggested that education philosophy courses in teacher education should be taken as a compulsory course in education programs. Findings from the research show that some of the teachers' beliefs on education are perennialism and essentialism, and their views on the teaching-learning process are traditional. Teachers working at all levels, by means of these findings, can be advised to organize professional development activities based on the teaching philosophy and the teaching-learning approach that our education system is based on. This research has been carried out with the teachers who are in currently working and similar research can be carried out with teacher candidates.

\section{References}

Alkın-Şahin, S., Tunca, N., \& Ulubey, Ö. (2014). Öğretmen adaylarının eğitim inançlanı ile eleştirel düşünme eğilimleri arasındaki ilişki. Illköğretim Online, 13(4), 1473-1492.

Altınkurt, Y., Yılmaz, K., \& Oğuz, A. (2012). İlköğretim ve ortaöğretim okulu öğretmenlerinin eğitim inançları. Ondokuz Mayıs Üniversitesi Eğitim Fakültesi Dergisi, 31 (2), 1-19.

Applefield, J. M., Huber,R., \& Moallem, M. (2000). Constructivim in theory and practice: Toward a beter understanding. High School Journal, 84(2), 35-53.

Akgün, İ. (2015). Sınıf öğretmeni adaylarında eleştirel düşünce yönelimleri ile eğitim inançları arasındaki ilig̈kinin incelenmesi. Yayınlanmamış yüksek lisans tezi. Dumlupınar Üniversitesi, Eğitim Bilimleri Enstitüsü, Kütahya.

Arslan, A. (2002). Felsefeye giriş. Ankara: Vadi Yayınları.

Aydın, Ö. Tunca, N., \& Alkın-Şahin, S. (2015). Fen bilgisi öğretmen adaylarının öğretme ve öğrenme anlayışlarının çeşitli değiş̧kenler açısından incelenmesi. Kastamonu Eğitim Dergisi, 23(3), 13311346.

Aykan, A. (2014). Ortaokul öğretmenlerinin yapılandırmacı yaklaşım ile ilgili yeterlik düzeylerinin incelenmesi. Yayınlanmamış Yüksek lisans Tezi. Yüzüncü Yıl Üniversitesi.

Aypay, A. (2011). Öğretme ve öğrenme anlayışları ölçeği'nin Türkçe uyarlaması ve epistemolojik inançlar ile öğretme ve öğrenme anlayışları arasındaki ilişki. Kuram ve Uygulamada Eğitim Bilimleri, 11(1), 7-29.

Aslan, S. (2017). An investigation of the educational beliefs of primary school teachers in terms of several variables. Kastamonu Education Journal, 25(4), 1453-1458.

Bakır, K. (2014). Demokratik eğitim. John Dewey’in eğitim felsefesi üzerine. (2. Baskı). Ankara: Pegem Akademi Yayıncilik.

Bandura, A. (1977). Self-efficacy: toward a unifying theory of behavioral change. Psychological Review, 84, 191-215. 
Baş, G. (2014). İlköğretim öğretmenlerinin öğretme-öğrenme anlayışlarının bazı değişkenler açısından değerlendirilmesi. Dicle Üniversitesi Ziya Gökalp Ĕ̈itim Fakültesi Dergisi, 22, 18-30.

Beytekin, F. O., \& Kadı, A. (2015). Öğretmen adaylarının eğitim inançları ve değerleri üzerine bir çalışma. International Journal of Social Science, 31, 327-341.

Biçer, B., Er, H., \& Özel, A. (2013) Öğretmen adaylarının epistemolojik inançları ve benimsedikleri eğitim felsefeleri aras ındaki ilişki. Ĕgitimde Kuram ve Uygulama, 9(3), 229-242.

Bilhan, S. (1991). Eğitim felsefesi. Ankara: Ankara Üniversitesi Eğitim Bilimleri Fakültesi Yaymları.

Brooks, J. G., \& Brooks, M. G. (1999). In search of understanding: The case for constructivist classrooms. Alexandria, VA: Association for Supervision and Curriculum Development.

Brown, D. F., \& Rose, T. J. (1995). Self-reported classroom impact of teachers' theories about learning and obstacles to implementation. Action in Teacher Education, 17(1), 20-29.

Büyükdüvenci, S. (1994). Varoluşçuluk ve eğitim. Ankara: Ankara Üniversitesi Yayınları.

Büyüköztürk, Ş., Kılı̧̧ Çakmak, E., Akgün, Ö. E. Karadeniz, Ş., \& Demirel, F. (2015). Bilimsel araştırma yöntemleri. (Geliştirilmiş 19. Baskı). Ankara: Pegem Akademi Yayıncıllk.

Cannon, J. (1997). The constructivist learning environment survey may help halt student exodus from college science courses. Journal of College Science Teaching, 27(1), 67-71.

Cevizci, A. (2000). Paradigma felsefe sözlüğ̈̈ (4. basım). İstanbul: Paradigma Yayınları.

Chan, K. W., \& Elliott, R. G. (2000). Exploratory study of epistemological beliefs to hong kong teacher education students: Resolving conceptual and empirical issues. Asia Pacific Journal of Teacher Education, 28(3), 225-234.

Chan, K. W., \& Elliott, R. G. (2004). Relational analysis of personal epistemology and conceptions about teaching and learning. Teaching and Teacher Education, 20(8), 817-831.

Cheng, M. M., Chan, K. W., Tang, S. Y., \& Cheng, A. Y. (2009). Pre-service teacher education students' epistemological beliefs and their conceptions of teaching. Teaching and Teacher Education, 25(2), 319-327.

Creswell, J., \& Plano Clark, V. L. (2007). Understanding mixed methods research. In J. Creswell (Ed.), Designing and conducting mixed methods research (pp. 1-19). Thousand Oaks, CA: Sage.

Çelik, R., \& Orçan, F. (2016). Öğretmen adaylarının eğitim inançları üzerine bir çalışma. Eğitimde Kuram ve Uygulama, 12(1), 63-77.

Demirel, Ö. (2007). Eğitimde program geliştirme (10. Bask1). Ankara: Pegem A Yayıncıllk.

Doğanay, A. (2011). Hizmet öncesi öğretmen eğitiminin öğretmen adaylarının felsefi bakış açılarına etkisi. Eğitim ve Bilim, 36(161), 332-348.

Doğanay, A., \& Sarı, M. (2003). İlköğretim öğretmenlerinin sahip oldukları eğitim felsefelerine ilişkin algılarının değerlendirilmesi "öğretmenlerin eğitim felsefeleri". Türk Eğitim Bilimleri Dergisi, 1(3), 321-337.

Duman, B., \& Ulubey, Ö. (2008). Öğretmen adaylarının benimsedikleri eğitim felsefelerinin öğretim teknolojilerini ve interneti kullanma düzeylerine etkisi ile ilgili görüşleri. Muğla Üniversitesi Sosyal Bilimler Enstitüsü Dergisi, 20, 95-114.

Eggen, P., \& Kauchak, D. (2001). Educational psychology: windows on classrooms. (5th ed.). Upper Saddle River, NJ: Prentice Hall.

Eisner, E. W. (1992). Curriculum ideologies. İçinde P. W. Jackson (Ed.), Handbook of research on curriculum (pp. 302-426). New York: Macmillan.

Ekinci N. (2016). Sınıf öğretmenlerinin öğretme-öğrenme anlayışları ve öğrenen özerkliğini destekleyici davranış lan aras ındaki ilişkiler. Akdeniz Eğitim Araştırmaları Dergisi, 19, 1-16.

Engin, G., \& Daşdemir, İ. (2015). Sunıf öğretmenlerinin öğretme ve öğrenme anlayışlarının çeşitli değişkenler açıs indan incelenmesi. International Journal of Social Science, 33, 425-432.

Ennis, C. D., Cothran, D. J., \& Loftus, S. J. (1997). The influence of teachers' educational beliefs on their knowledge organization. Journal of Research and Development in Education, 30(2), 73-86.

Erbaş, M. K. (2013). Determination of physical education teachers' educational beliefs. International Journal of Academic Research, 5(5), 386-392.

Ergün, M. (2012). Eğitimin felsefi temelleri. Ö. Demirel ve Z. Kaya (Ed.) Eğitim Bilimine Giriş içinde (s.199-218).Ankara: Pegem Akademi Yayıncılık.

Erkuş, A. (2011). Davranış bilimleri için bilimsel araş̧ırma süreci. Ankara: Seçkin Yayıncıllk.

Field, A. (2009). Discovering statistics using SPSS. (3rd ed.). London, England: Sage Publications Inc. 


\section{THE RELATIONSHIP BETWEEN TEACHERS' EDUCATIONAL BELIEFS AND}

TEACHING-LEARNING CONCEPTIONS: A MIXED METHOD STUDY

Gutek, G. L. (2007). Eğitime felsefi ve ideolojik yaklaşımlar. (Çev. Nesrin Kale). Ankara: Ütopya Yaymevi.

Güneş, F. (2014). Tanım ve kavramlar. F. Güneş (Ed.) Öğretim İlke ve Yöntemleri içinde (s. 2-22). Ankara: Pegem Akademi.

Harvey, O. J. (1986). Belief systems and attitudes toward death penalty and otherpunishments. Journal of Psychology, 54 143-159.

Hashweh, M. Z. (1996). Effects of science teachers' epistemological beliefs in teaching. Journal of Research in Science Teaching, 33(1), 47-63.

Hofer, B. K. (2002). Personel epistemology as a psychological and educational construct: An introduction. In B. K. Hofer \& P. R. Pintrich (Eds.), Personal epistemology: The psychology of beliefs about knowledge and knowing (pp. 3-14). Mahwah, NJ: Lawrence Erlbaum Associates.

Hofer, B. K., \& Pintrich, P. R. (1997). The development of epistemological theories: Beliefs about knowledge and knowing and their relation to learning. Review of Educational Research, 67, 88140. http://dx.doi.org/10.3102/00346543067001088.

Hoy, W. K., \& Miskel, C. G. (2001). Educational administration: theory, research and practice. $6^{\text {th }}$ edition. Boston: McGraw-Hill.

Ilgaz G., Bülbül T., \& Çuhadar, C. (2013). Öğretmen adaylarının eğitim inançları ile öz-yeterlik algıları arasındaki ilişkinin incelenmesi. Abant İzzet Baysal Üniversitesi Ĕgitim Fakültesi Dergisi, 13(1), 50-65.

Kagan, D. M. (1992). Implications of research on teacher belief. Educational Psychologist, 27(1), 6590.

Kanatll, F., \& Schreglman, S. (2014). İlköğretim öğretmenlerinin sahip oldukları eğitim felse-felerine ilişkin algılarının değerlendirilmesi. Gümüşhane Üniversitesi Sosyal Bilimler Elektronik Dergisi, 9, 128-138.

Karadağ, E., Baloğlu, N., \& Kaya, S. (2009). Okul yöneticilerinin eğitim felsefesi akımlarını benimseme düzeylerine ilişkin ampirik bir çalışma. Kaygı: Uludağ Üniversitesi Felsefe Dergisi, $12,181-200$.

Kauchak, D. P., \& Eggen, P. D. (2003). Learning and teaching research-based methods. The USA: Pears on Education, Inc.

Kaygısız, İ. (1997). Eğitim felsefesi ve Türk eğitim sisteminin felsefi temelleri. Eğitim ve Yaşam 8, 515.

Kazu, H. (2002). Ĕgitim ve felsefe. M. Taşpınar (Ed.). Öğretmenlik Mesleği içinde (s.64-82). Elazı̆̆: Elazı̆ Üniversite Yaymevi.

Krows, A. J. (1999). Preservice Teachers' Belief Systems and Attitudes Toward Mathematics in the Context of a Progressive Elementary Teacher Preparation Program. Unpublished Doctoral Dissertations. The University of Oklohama. Norman, Oklohoma.

Leavy, A. M., McSorley, F. A., \& Boté, L. A. (2007). An examination of what metaphor construction reveals about the evolution of preservice teachers' beliefs about teaching and learning. Teaching and Teacher Education, 23, 1217-1233.

Lefebvre, S., Deaudelin, D., \& Loiselle, J. (2006). ICT implementation stages of primary school teachers: The practices and conceptions of teaching and learning. Paper presented at the Australian Association for Research in Education National Conference, Adelaide, Australia, 27th - 30th November, 2006.

McMillan, J. H., \& Schumacher, S. (2006). Research in education: Evidence-based inquiry. Boston: Pearson Education Ltd.

Miles, M. B., \& Hubermann, A. M. (1994). Qualitative data analysis. Thousand Oaks, CA: Sage Publication.

Nespor, J. (1987). The role of beliefs in the practice of teaching. Journal of Curriculum Studies, 19(4), $317-328$.

Oğuz, A. (2011). Öğretmen adaylarının demokratik değerleri ile öğretme ve öğrenme anlayışları. Değerler Ĕ̈itimi Dergisi, 9(22), 139-160.

Ornstein, A. C. \& Hunkins, F. P. (1993). Curriculum: foundations, principles and issues. New Jersey: Prentice Hall, Englewood Cliffs.

Ornstein, A., \& Hunkins, F. (2009) Curriculum design. In Curriculum: Foundations, principles and issues (pp. 181-206). Boston, MA: Pearson/Allyn and Bacon. 
Pajares, F. M. (1992). Teachers' beliefs and educational research: cleaning up a messy construct. Review of Educational Research, 62, 307-332.

Phillips, D. C. (2000). An opinionated account of the constructivist landscape. Phillips, D. C. (Ed.). Constructivism in education: Opinions and second opinions on contoversial issues in (pp. 1-16). Chicago, Illionis: The University of Chicago Press.

Romanowski, M. H. (1997). Teachers' Lives and Beliefs: Influences That Shape the U.S. History Curriculum. Paper presented at the Annual Meeting of the American Educational Research Association (Chicago, IL, April 24-28, 1997).

Rienties, B., Lygo-Baker, S., \& Brouwer, N. (2013). The effects of online professional development on higher education teachers' beliefs and intentions towards learning facilitation and technology. Teaching and Teacher Education, 29, 122-131.

Riggs, I. M., \& Enochs, L.G. (1990). Toward the development of an elementary teacher's science teaching efficacy beliefs instrument. Science Education, 74(6), 625-637.

Savaşçı Açikalın, F. (2009). Teacher beliefs and practice in science education. Asia-Pacific Forum on Science Learning and Teaching, 10(1), 1-14.

Schunk, D. H. (2014). Learning theories: An educational perspective. Upper Saddle River, New Jersey: Pearson Education, Inc.

Sherman T. M., \& Kurshan B. L. (2005). Constructing learning: Using technology to support teaching for understanding. Learning and Leading with Technology, 32 (5), 10-13.

Sigel, I. E. (1985). A conceptual analysis of beliefs. In I. E. Sigel (Ed.), Parental belief systems: The psychological consequences for children (pp. 345-371). Hillsdale, NJ: Erlbaum.

Sönmez, V. (2012). Eğitimin felsefi temelleri. Veysel Sönmez (Ed.), Eğitim Bilimine Giriş içinde (s.61-93). Ankara: Anı Yayıncillk.

Sözer, E. (2002). Ĕgitimin felsefi temelleri. Ersan Sözer (Ed.), Öğretmenlik Mesleğine Giriş içinde (s.81-94). Eskişehir: Anadolu Üniversitesi Yayınları.

Türkeli, A. (2011). Beden Eğitimi Öğretmenlerinin Eğitim Felsefeleri ve Teknolojiye Karş1 Tutumları. Yayınlanmamış Yüksek Lisans Tezi. Gazi Üniversitesi Eğitim Bilimleri Enstitüsü. Ankara.

Uğurlu, C. T., \& Çalmaşur, H. (2017). Öğretmenlerin ve öğretmen adaylarının eğitim inançlarına ilişkin görüşleri: bir karma yöntem çalışması. Adlyaman Üniversitesi Sosyal Bilimler Enstitüsü Dergisi, 9(25), 230-273.

Varış, F. (1994). Ë̆itim bilimine giriş. Konya: Atlas Kitabevi.

Wiles, J., \& Bondi, J. (2002). Curriculum Development: A guide to practice. (6 $6^{\text {th }}$ Ed.). Upper Saddle River, NJ: Merrill Prentice Hall.

Yazıcı, T. (2017). Müzik öğretmeni adaylarının eğitim felsefesi inançları. Kastamonu Eğitim Dergisi, 25(2), 1-16.

Yero, J. L. (2002). Teaching in mind: How teacher thinking shapes education. Hamilton, MT: MindFlight Publishing.

Yıdırım, A., \& Şimşek, H. (2016). Sosyal bilimlerde nitel araştırma yöntemleri (Genişletilmiş 10. Baskı). Ankara: Seçkin Yayıncılik.

Yılmaz, K., Altınkurt, Y., \& Çokluk, Ö. (2011). Eğitim inançları ölçeğinin geliştirilmesi: Geçerlik ve güvenirlik çalışması. Kuram ve Uygulamada Eğitim Bilimleri, 11 (1), 335-350.

Yılmaz, K., \& Tosun, M. F. (2013). Öğretmenlerin eğitim inançları ile öğretmen öğrenci ilişkilerine yönelik görüşleri aras nndaki ilişki. Eğitim ve Öğretim Araştırmaları Dergisi, 2(4), 205-218. 
